\title{
Chelate-assisted phytoextraction of cadmium from a mine soil by negatively charged sunflower
}

\author{
I. Tahmasbian $\cdot$ A. A. Safari Sinegani
}

Received: 25 October 2012/Revised: 7 June 2013/Accepted: 9 October 2013/Published online: 30 October 2013

(C) Islamic Azad University (IAU) 2013

\begin{abstract}
The effects of some chelating agents and electricity on cadmium phytoextraction from a mine soil were examined in pot culture of sunflower to achieve more remediation efficiency. At the beginning of the flowering stage, ethylene-diamine-tetra-acetic acid (EDTA) as a chemical chelator, cow manure extract (CME) and poultry manure extract (PME) as organic chelators were applied $\left(2 \mathrm{~g} \mathrm{~kg}^{-1}\right.$ soil) during irrigation. Seven days later, Helianthus annuus was negatively charged by inserting a stainless steel needle in the lowest part of the stem with 10 and $30 \mathrm{~V}$ direct current electricity for $1 \mathrm{~h}$ each day for 14 days. Afterward, concentration of cadmium in roots and shoots, cadmium translocation factor (TF), cadmium uptake index (UI) and soil available (diethylene-triaminepenta-acetic acid extractable) cadmium were measured. Results indicated that EDTA reduced roots dry weight while none of the roots and shoots was affected by other chelating agents and by electrical treatment as well. Highest concentration of cadmium in shoots was measured in $10 \mathrm{~V}$-control with no significant differences with $30 \mathrm{~V}$ PME and $30 \mathrm{~V}$-EDTA. Utilization of chelating agents did not increase the cadmium TF and cadmium UI while highest values for cadmium $\mathrm{TF}$ and cadmium UI were observed in 10 and $30 \mathrm{~V}$ treatments, respectively. Available cadmium in the soil near root system treated with 10 and $30 \mathrm{~V}$ was relatively lower compared with the soil far from root system. Results of this experiment indicated that charging the plant with direct current electricity ameliorated the efficiency of cadmium phytoremediation.
\end{abstract}

I. Tahmasbian $(\bowtie) \cdot$ A. A. Safari Sinegani

Department of Soil Science, Bu-Ali Sina University,

Hamadan, Iran

e-mail: I.tahmasbian@basu.ac.ir
Keywords Contaminated soil · Electrokinetic . Helianthus annuus · Phytoremediation

\section{Introduction}

Due to the toxicity and carcinogenic effects on human, animals, and plants, heavy metal pollution is one of the major anxieties nowadays (Giannis et al. 2010). The widespread use of sewage sludge, waste waters, pesticide in agriculture and the emissions of vehicle exhausts, mining, and smelting has resulted in large accumulation of heavy metals in soils (Shi et al. 2009; Dede et al. 2012). While it is believed that soil contamination with cadmium $(\mathrm{Cd})$ is the most serious health risk, $\mathrm{Cd}$ is likely to be accumulated into the soil surface under the influence of human activities (Kabata-pendias 2011). It is reported that the Cd concentration in top soil can be very high near $\mathrm{Pb}$ and $\mathrm{Zn}$ mines and especially smelting operations (Kabata-pendias 2011).

There are several reviews explaining that the phosphate fertilizers and sewage sludge are also accepted as important sources of Cd in soil (Fleischer et al. 1974; Williams and David 1976, 1981; Street et al. 1977; Smolders and Degryse 2006). The polluted soils with large quantities of contaminants, in turn, can be a long-term source of pollution for groundwater and the ecosystems (Kabata-pendias 2011); therefore, remediation of these contaminants for decreasing subsurface contamination is very important ( $\mathrm{Li}$ et al. 2009). In situ technologies are noninvasive techniques used to remove pollutants from soils (Pazos et al. 2010). Phytoremediation is one of the in situ procedures, which has been applied by many scientists (Huang et al. 1997; Kulli et al. 1999; Cooper et al. 1999; Safari Sinegani and Khalilikhah 2011; Safari Sinegani and Ahmadi 2012) and has received increasing attention as a cost-effective alternative to usual 
engineering-based remediation approaches (Salt et al. 1998). Only plants with high biomass and high metal uptake capacity are suitable for phytoextraction of contaminants from soils. Because most hyperaccumulators have low annual biomass, some researchers aimed to increase the availability of heavy metals in soil for plants (Wong et al. 2004). Ethylene-diamine-tetraacetic acid (EDTA) was found to be the most effective chelating agent to enhance heavy metal bioaccumulation (Ebbs et al. 1997; Huang et al. 1997; Wu et al. 1999; Safari Sinegani and Khalilikhah 2011). Application of EDTA in soil causes a large fraction of total metals to become available for phytoextraction (Elliott and Brown 1989; Haag-Kerwer et al. 1999) and also enhances the root metal flux through the apoplast and then subsequently increase metal translocation factor (TF) (Hernandez-Allicac et al. 2007).

On the other hand, electrokinetic decontamination of soil is one of the promising remediation techniques that has been utilized to extract various contaminants from the soil, sediment, or sludge (Kim et al. 2009; Chen et al. 2011; Alcantara et al. 2012; Gomes et al. 2012).

The principle of operation of electrokinetic is to use a direct electrical field in soil to run pollutants within the soil pores toward the electrode (Wang et al. 2009). The major mechanisms of electrokinetic remediation are electromigration and electroosmosis (Kim et al. 2002). Electromigration is defined as a directional movement in which ions move toward the electrode with opposite charge (Zhou et al. 2006). Hence, metal ions and complexes can move under electrokinetic treatments and absorb easily by plants cultured near electrodes (Cang et al. 2011). The other process caused by applied electrical potential is known as electroosmosis, i.e., the movement of an ionic liquid under the action of an applied electric field which relates to a charged surface (Giannis et al. 2007). Due to the hydrolysis reaction of water during the electrokinetic process, a hydrogen ion is produced at the anode. While moving toward the cathode, the $\mathrm{H}+$ exchanges with the soil exchangeable cations (Kim et al. 2009). The released metal ions move toward the cathode in electromigration. An acidic solution can be used to improve the removal efficiency of heavy metals from soils (Baek et al. 2009).

In recent years, combination of electrokinetic remediation and phytoremediation to decontaminate metal-polluted soil has attracted many researches (O'Connor et al. 2003; Lim et al. 2004; Cang et al. 2011; Bi et al. 2011). However, there was no study on the effects of choosing a plant as cathode in electrokinetic phytoremediation. The objective of this study was to evaluate the effects of application of some chelating agents and electrical fields on Cd uptake by Helianthus annuus from a calcareous mine soil to achieve more remediation efficiency. Here, the sunflower was negatively charged by inserting a stainless steel needle in the lowest part of the stem directly. The current study was conducted in the spring of 2012 in Hamadan Province, Iran.

\section{Materials and methods}

Primary analysis of soil

The experimented soil was gathered from a pasture situated around $\mathrm{ab}$ and $\mathrm{Zn}$ mine in Hamadan Province, Iran. Selected soil properties were determined according to the standard methods. Particle size was measured using the hydrometer method. Equivalent calcium carbonate (ECC) was measured by back titration procedure so that $1 \mathrm{~g}$ of the experimental soil was weighted and put into a $250 \mathrm{~cm}^{3}$ beaker; $100 \mathrm{~cm}^{3}$ of pure water was added followed by $25 \mathrm{~cm}^{3} 0.5 \mathrm{M}$ sulfuric acid. When effervescence has finished, the solution was heated for 3 min. The mixture was filtered, and soil was washed with distilled water 3 times. All filtered waters titrated with standard $0.25 \mathrm{M}$ sodium hydroxide solution until the appearance of a pink color of phenolphthalein indicator. Soil $\mathrm{pH}$ and electrical conductivity (EC) were measured in a 1:5 soil:water extract after shaking for $30 \mathrm{~min}$. Organic carbon (OC) was analyzed by dichromate oxidation and titration with ferrous ammonium sulfate. Cation-exchange capacity (CEC) was measured by the method of sodium saturation. It was done by addition of $33 \mathrm{ml} \mathrm{Na}$ acetate $(1 \mathrm{M})$ on $5 \mathrm{~g}$ soil in $50 \mathrm{ml}$ centrifuge tube for three times, and extraction was done to remove the released cations from soil solution (Bower et al. 1952). Excess $\mathrm{Na}$ acetate was removed with 3 washing ( $33 \mathrm{ml}$ each) of $95 \%$ ethanol. The exchangeable Na was extracted with 3 washing (33 ml each) of $1 \mathrm{~N}$ ammonium acetate and then measured by a flame photometer instrument. These soil characteristics were measured according to methods of soil analysis published by Soil Science Society of America (SSSA) (Klute 1986; Page et al. 1992). Texture of the experimented soil was loamy. The soil $\mathrm{pH}, \mathrm{EC}, \mathrm{OC}, \mathrm{ECC}$, and CEC were 7.7, $580.65 \mu \mathrm{s} \mathrm{cm}^{-1}, 0.59,22 \%$, and $14.24 \mathrm{cmolc}$ (+) $\mathrm{kg}^{-1}$, respectively. Soil total-Cd was extracted by $\mathrm{HNO}_{3}-$ $\mathrm{H}_{2} \mathrm{O}_{2}-\mathrm{HCl}$ (USEPA 2000), and soil available Cd was analyzed by diethylene-triamine-penta-acetic acid (DTPA) so that $10 \mathrm{~g}$ of air-dry soil was shaken with $20 \mathrm{ml}$ of extractant (0.005 M DTPA, 0.1 M triethanolamine, and $0.01 \mathrm{M} \mathrm{CaCl}_{2}$, with a $\mathrm{pH}$ of 7.3.) for $2 \mathrm{~h}$. The leachate was filtered, and $\mathrm{Cd}$ was measured in the filtrate by atomic absorption spectrophotometry (Lindsay and Norvell 1978). Soil Cd active fractions were extracted by the modified Sposito et al. (1982) method and analyzed by atomic absorption spectrometry (Varian 220). The soil total-Cd, carbonate-bound, organicbound, soluble and available $\mathrm{Cd}$ were 10.20, 2.11, 1.54, 1.31, and $0.03 \mathrm{mg} \mathrm{kg}^{-1}$, respectively. Total amount of $\mathrm{Cd}$ in manure extracts was too low and not detectable by the atomic absorption instrument. 


\section{Experimental setup}

A seven and half kilograms of Cd-polluted (air-dried) soil was fertilized with $150 \mathrm{mg} \mathrm{kg}^{-1} \mathrm{~N}$ (about $321.4 \mathrm{mg} \mathrm{kg}^{-1}$ of urea), $100 \mathrm{mg} \mathrm{kg}^{-1} \mathrm{~K}$ (about $233.1 \mathrm{mg} \mathrm{kg}^{-1}$ of $\mathrm{K}_{2} \mathrm{SO}_{4}$ ), and $70 \mathrm{mg} \mathrm{kg}^{-1} \mathrm{P}$ (about $307.1 \mathrm{mg} \mathrm{kg}^{-1}$ of $\mathrm{KH}_{2} \mathrm{PO}_{4}$ ) and put into plastic pot (diameter $22 \mathrm{~cm}$ and height $20 \mathrm{~cm}$ ). Each pot was divided into two parts (Fig. 1a) with a cylindrical vertical galvanized-size mesh $(25 \mu \mathrm{m}$ pore size, $11 \mathrm{~cm}$ diameter, and $20 \mathrm{~cm}$ height) to separate rhizospheric and non-rhizospheric soil. H. annuus seeds were germinated on filter paper and transferred to the center of cylindrical galvanized-iron mesh (center of the pots), and the pots were daily irrigated. The pots were arranged in a completely randomized experimental design with 3 replicates.

Four graphite electrodes $(15 \times 1 \times 1 \mathrm{~cm})$ were placed around the pots as anodes (Fig. 1a, b). The plant was used as a cathode instead of a central graphite electrode. The sunflower was negatively charged by inserting a stainless steel needle in the lowest part of the stem directly (Fig. 1c). Electrical fields were produced by DC electricity $(0,10$ and $30 \mathrm{~V})$ with a TNIU power supply instrument model TU305D.
The experiment was set out in a glasshouse as a completely randomized design. Because of favorable conditions for plant growth in spring, all of optimizing systems of the glasshouse were switched off. After 53 days from culturing the sunflowers in the pots, at the beginning of flowering stage, the soils were treated by $2 \mathrm{~g} \mathrm{~kg}^{-1}$ soil of EDTA as a chemical chelator, cow manure extract (CME), and poultry manure extract (PME) as organic chelators. The chelating agents were dissolved in irrigation water and applied. Seven days later (60 days from the beginning), DC electricity was applied (10 and $30 \mathrm{~V})$. Electrical fields were applied for an hour each day for 14 days (Lim et al. 2004). The EDTA was purchased in reagent grade form Sigma Chemical. The CME and PME were prepared after extracting of 1:5 manure/distilled water suspension by shaking (120 rounds per min for $20 \mathrm{~min}$ ), centrifuging, and filtering. The $\mathrm{pH}$ of CME and PME were 7.72 and 8.2, respectively. Total solid of CME and PME was measured for calculating the required amounts of amendment for soil treatment $\left(2 \mathrm{~g} \mathrm{~kg}^{-1}\right.$ soil). Two weeks after the application of electricity ( 74 days after starting the experiment), the plants were carefully harvested for shoot and root analysis at the flowering stage.
Fig. 1 a Diagram of the soil remediation system, b graphite electrodes placed around the pots as anodes, c stainless steel needle inserted in the lowest part of sunflower stem for charging the plant with negative charge
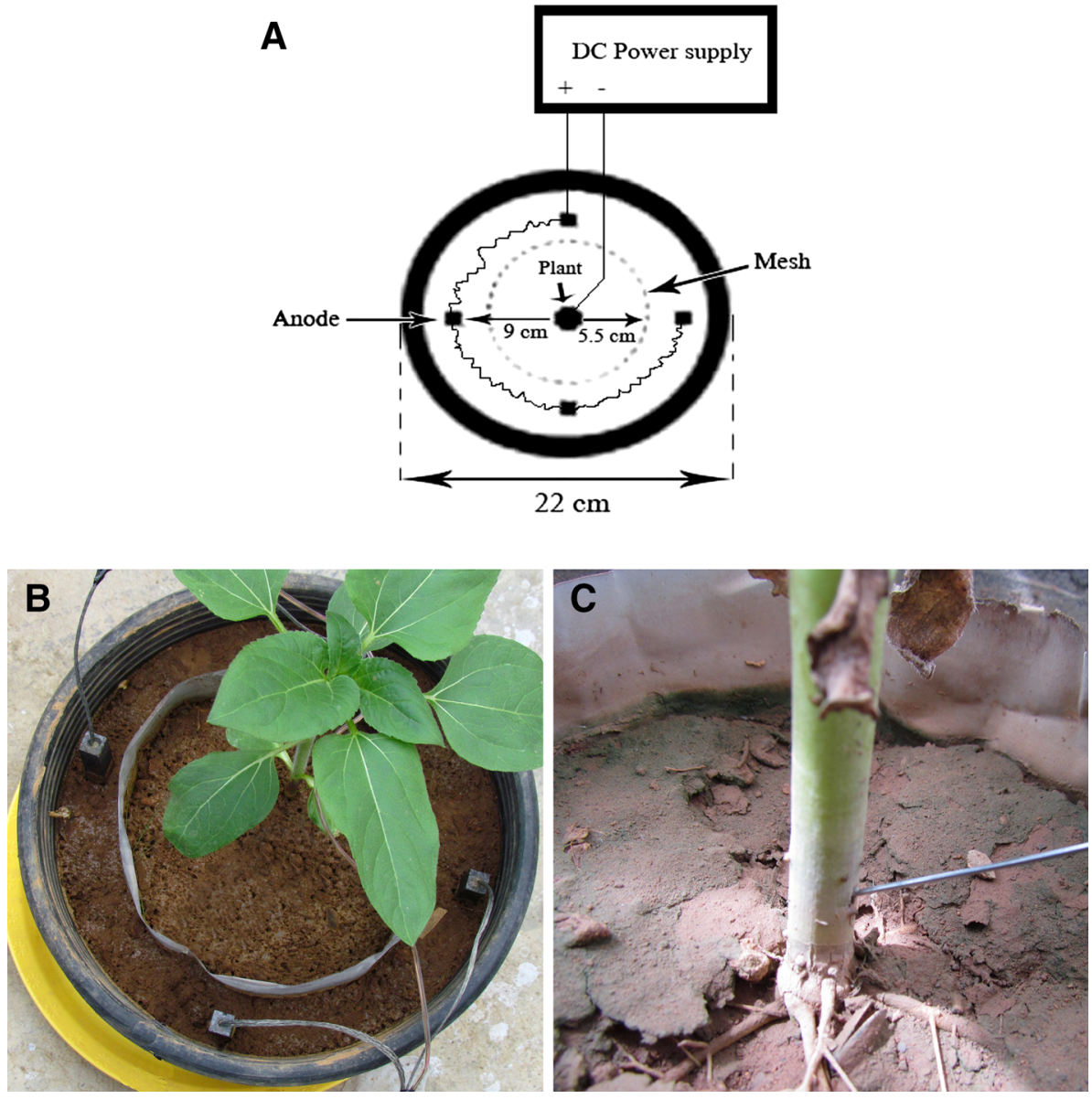
Plant analysis

The plants were harvested by cutting the stem $1 \mathrm{~cm}$ above the soil surface carefully. The harvested plants (shoot and root) were washed with $0.1 \mathrm{M} \mathrm{HCl}$, rinsed with de-ionized water, and then dried in the oven at $75^{\circ} \mathrm{C}$ for $48 \mathrm{~h}(\mathrm{Lim}$ et al. 2004; Bi et al. 2011). Then the dried shoots and roots were weighted and milled into fine powder using a grinding machine and stored in glass containers until analysis. $0.5 \mathrm{~g}$ of shoots and roots were placed in a glass tube and $2 \mathrm{ml}$ of concentrated nitric acid was added. The tubes were heated on an electrical heater at $65^{\circ} \mathrm{C}, 60 \mathrm{~min}$ and then $120^{\circ} \mathrm{C}$, $60 \mathrm{~min}$. Once cooled to room temperature, $0.2 \mathrm{ml}$ of hydrogen peroxide was added to each tube and the mixture was left for $30 \mathrm{~min}$ to complete reaction. The final volume was brought to $25 \mathrm{ml}$ (Figueroa et al. 2008). After appropriate dilution, the determination of $\mathrm{Cd}$ was carried out by atomic absorption spectrometry (Varian model 220).

The metal TF was calculated from the shoot and root $\mathrm{Cd}$ concentrations. It describes the ability of the plant to translocate Cd from root to shoot (Li et al. 2006). The Cd TF was calculated by Eq. 1:

$$
\begin{aligned}
\mathrm{TF}= & \mathrm{Cd} \text { concentration in shoot }\left(\mathrm{mg} \mathrm{kg}^{-1}\right) \\
& \div \mathrm{Cd} \text { concentration in root }\left(\mathrm{mg} \mathrm{kg}^{-1}\right)
\end{aligned}
$$

Cadmium uptake index (UI) was calculated by Eq. 2 (Bi et al. 2011):

$$
\begin{aligned}
\mathrm{UI}(\mathrm{mg} \mathrm{pot} & -1)= \\
& \mathrm{Cd} \text { concentration in shoot }\left(\mathrm{mg} \mathrm{kg}^{-1}\right) \\
& \times \text { Shoot dry weight of plant }\left(\mathrm{kg} \mathrm{pot}^{-1}\right)
\end{aligned}
$$

Soil chemical analysis

The soil out of the galvanized-iron mesh $(5.5 \mathrm{~cm}$ between iron mesh and edge of pot) was collected and labeled as anodic soil or soil far from root system (FFRS). The soil within the galvanized-iron mesh $(5.5 \mathrm{~cm}$ radius from pot center) was collected and labeled as cathodic soil or soil near root system (NRS). The soil available $\mathrm{Cd}$ was extracted by DTPA and analyzed by atomic absorption spectrometry on a Varian 220 instrument (Lindsay and Norvell 1978).

\section{Statistical analysis}

This experiment was considered a completely randomized design as factorial in three replicates. Applied factors were chelating agents (no chelating agent, EDTA, CME, and PME) and electrical fields produced by DC electricity $(0,10$ and $30 \mathrm{~V})$. Analysis of variance was used to determine the significance of the effects of chelating agents and negatively charging of plant on $\mathrm{Cd}$ phytoremediation indices and soil available $\mathrm{Cd}$ in comparison with the control. Data were statistically analyzed for standard deviation, means were calculated, and Duncan's new multiple range tests were performed to assess the effects. Statistical analyses and graphical works were performed on the SAS 9.1 software and Microsoft Excel 2010.

\section{Results and discussion}

\section{Shoot and root dry weight}

Application of electrical fields had no significant effect on the plant root and shoot dry weights (Table 1). It can be attributed to the late and short time of application of electricity. Table 2 represented values of shoots dry weight of $H$. annuus. Bi et al. (2011), by the application of DC electrical fields in soil, have also reported that the application of electrical field did not affect the plant biomass significantly; However, the application of chelating agents had significant effect on the root dry weight of sunflower $(p<0.05)$. EDTA compared with CME and PME decreased root dry weight of plant significantly. Root biomass of sunflower which was treated with EDTA $\left(2.41 \pm 0.80 \mathrm{~g} \mathrm{pot}^{-1}\right)$ was significantly lower than its root biomass in CME $\left(4.33 \pm 1.02 \mathrm{~g} \mathrm{pot}^{-1}\right)$ and PME $\left(4.29 \pm 2.04 \mathrm{~g} \mathrm{pot}^{-1}\right)$ treatments. However, the roots and shoots dry weights of sunflower treated with different chelating agents had no significant difference with those in control soil $\left(3.69 \pm 1.39 \mathrm{~g} \mathrm{pot}^{-1}\right)$. Many scientists have reported that the application of EDTA in soil reduces plant's root and shoot biomass (Safari Sinegani and Khalilikhah 2011). This different result may be related to the time of application of chelating agents in soil. Safari Sinegani and Khalilikhah (2011) reported that when EDTA was applied late, negative effect of this treatment on plant growth and plant dry weight was markedly low.

Cadmium concentration in plant organs

Although it is considered that $\mathrm{Cd}$ is a nonessential element for metabolic processes, it can be effectively absorbed by both root and leaf systems of plants and also highly accumulate in soil organisms (Kabata-pendias 2011). The results showed that there is a significant $(p<0.01)$ interaction between the electrical fields and chelating agents' treatment on Cd concentrations in plant's root and shoot (Table 1).

As depicted in Table 3, the highest amount of $\mathrm{Cd}$ in shoots $\left(8.1 \mathrm{mg} \mathrm{kg}^{-1}\right)$ was found in the plants treated with $10 \mathrm{~V}$-control. The lowest amount of $\mathrm{Cd}$ concentration in shoot was observed in no voltage-control and no voltagePME treatments. On the other hand, highest amount of $\mathrm{Cd}$ concentration in roots $\left(6.68 \mathrm{mg} \mathrm{kg}^{-1}\right)$ was also measured in $10 \mathrm{~V}$-control treatment. It seems that the application of a 
Table 1 Analysis of variance (mean squares) of analyzed factors affected by chelating agents and electrical fields

\begin{tabular}{|c|c|c|c|c|c|c|c|c|c|}
\hline & \multirow[t]{2}{*}{$\mathrm{DF}$} & \multirow[t]{2}{*}{ SDW } & \multirow[t]{2}{*}{ RDW } & \multirow[t]{2}{*}{ Sh conc. } & \multirow[t]{2}{*}{$\mathrm{R}$ conc. } & \multirow[t]{2}{*}{$\mathrm{TF}$} & \multirow[t]{2}{*}{ UI } & \multicolumn{2}{|l|}{ A. $\mathrm{Cd}$} \\
\hline & & & & & & & & NRS & FFRS \\
\hline Electricity & 2 & $73.56 \mathrm{~ns}$ & $0.19 \mathrm{~ns}$ & $12.91 * *$ & $1.39 \mathrm{~ns}$ & $1.56^{* *}$ & $0.006^{*}$ & $10^{-3 * *}$ & $4 \times 10^{-4} \mathrm{~ns}$ \\
\hline Chelating agents & 3 & $30.20 \mathrm{~ns}$ & $6.47 *$ & $2.10 \mathrm{~ns}$ & $2.08 \mathrm{~ns}$ & $0.12 \mathrm{~ns}$ & $3 \times 10^{-4} \mathrm{~ns}$ & $10^{-3 * *}$ & $4 \times 10^{-4} \mathrm{~ns}$ \\
\hline Interaction & 6 & $45.95 \mathrm{~ns}$ & $2.24 \mathrm{~ns}$ & $5.57 * *$ & $4.44 * *$ & $0.42 \mathrm{~ns}$ & $0.003 \mathrm{~ns}$ & $0.01 * *$ & $7 \times 10^{-3 * *}$ \\
\hline Error & 24 & 30.41 & 1.99 & 0.71 & 0.85 & 0.19 & 0.001 & $10^{-4}$ & $3 \times 10^{-4}$ \\
\hline
\end{tabular}

$S D W$ shoot dry weight, $R D W$ root dry weight, Sh conc. shoot Cd concentration, $R$ conc. root Cd concentration, $T F \mathrm{Cd}$ translocation factor, $U I \mathrm{Cd}$ uptake index, $A$. $C d$ available (DTPA extractable) Cd, NRS soil near the root system, FFRS soil far from root system, $n s$ nonsignificant at 0.05

* Significant impacts at the 0.05 ;** significant impacts at the 0.01

Table 2 Shoots dry weight $\left(\mathrm{g} \mathrm{pot}^{-1}\right)$ of Helianthus annuus in chelating agents and electrical field treatments

\begin{tabular}{llll}
\hline $\begin{array}{l}\text { Electrical } \\
\text { treatment }\end{array}$ & $\begin{array}{l}\text { Shoots dry } \\
\text { weight }\end{array}$ & $\begin{array}{l}\text { Chelating agents } \\
\text { treatment }\end{array}$ & $\begin{array}{l}\text { Shoots dry } \\
\text { weight }\end{array}$ \\
\hline $30 \mathrm{~V}$ & $28.00^{\mathrm{a}}( \pm 6.06)$ & CME & $28.04^{\mathrm{a}}( \pm 4.79)$ \\
$10 \mathrm{~V}$ & $23.38^{\mathrm{a}}( \pm 5.57)$ & PME & $26.04^{\mathrm{a}}( \pm 4.68)$ \\
Control & $25.87^{\mathrm{a}}( \pm 5.57)$ & EDTA & $24.06^{\mathrm{a}}( \pm 5.45)$ \\
& & Control & $25.07^{\mathrm{a}}( \pm 8.43)$ \\
\hline
\end{tabular}

Values with different letters show significant differences at the 0.05 probability level for each treatment

$C M E$ cow manure extract, $P M E$ poultry manure extract

Table 3 Cadmium concentration in shoot and root $\left(\mathrm{mg} \mathrm{kg}^{-1}\right)$ of Helianthus annuus in different chelating agent and electrical field treatments

\begin{tabular}{lccc}
\hline & $30 \mathrm{~V}$ & $10 \mathrm{~V}$ & No voltage \\
\hline Shoot & & & \\
CME & $3.90^{\mathrm{ed}}( \pm 1.00)$ & $5.82^{\mathrm{bc}}( \pm 0.37)$ & $5.23^{\mathrm{dc}}( \pm 0.40)$ \\
PME & $7.35^{\mathrm{ab}}( \pm 1.63)$ & $5.98^{\mathrm{bc}}( \pm 0.55)$ & $3.37^{\mathrm{e}}( \pm 0.32)$ \\
EDTA & $6.58^{\mathrm{abc}}( \pm 0.88)$ & $6.37^{\mathrm{bc}}( \pm 0.80)$ & $5.67^{\mathrm{bc}}( \pm 1.17)$ \\
Control & $5.80^{\mathrm{bc}}( \pm 0.55)$ & $8.10^{\mathrm{a}}( \pm 0.92)$ & $3.15^{\mathrm{e}}( \pm 0.55)$ \\
Root & & & \\
CME & $3.18^{\mathrm{c}}( \pm 0.43)$ & $2.48^{\mathrm{c}}( \pm 0.41)$ & $5.63^{\mathrm{ab}}( \pm 0.63)$ \\
PME & $3.98^{\mathrm{bc}}( \pm 0.66)$ & $3.43^{\mathrm{c}}( \pm 1.28)$ & $3.47^{\mathrm{c}}( \pm 0.03)$ \\
EDTA & $3.82^{\mathrm{bc}}( \pm 0.74)$ & $4.25^{\mathrm{bc}}( \pm 1.47)$ & $3.80^{\mathrm{bc}}(<0.01)$ \\
Control & $3.48^{\mathrm{c}}( \pm 1.38)$ & $6.68^{\mathrm{a}}( \pm 1.02)$ & $4.18^{\mathrm{bc}}( \pm 0.71)$ \\
\hline
\end{tabular}

$C M E$ cow manure extract, $P M E$ poultry manure extract

Values with different letters show significant differences at the 0.05 probability level for each organ

medium voltage of DC electrical field between plant and soil can increase the accumulation of $\mathrm{Cd}$ in both root and shoot of sunflower. Application of higher voltage possibly increases insoluble form of $\mathrm{Cd}$ as a result of generating hydroxyl ions and increasing the soil $\mathrm{pH}$ during the hydrolysis of water. Treating the sunflower with $30 \mathrm{~V}$ CME causes the plant to reduce the accumulation of $\mathrm{Cd}$ in its root to the minimum level $\left(3.18 \mathrm{mg} \mathrm{kg}^{-1}\right)$. This may be

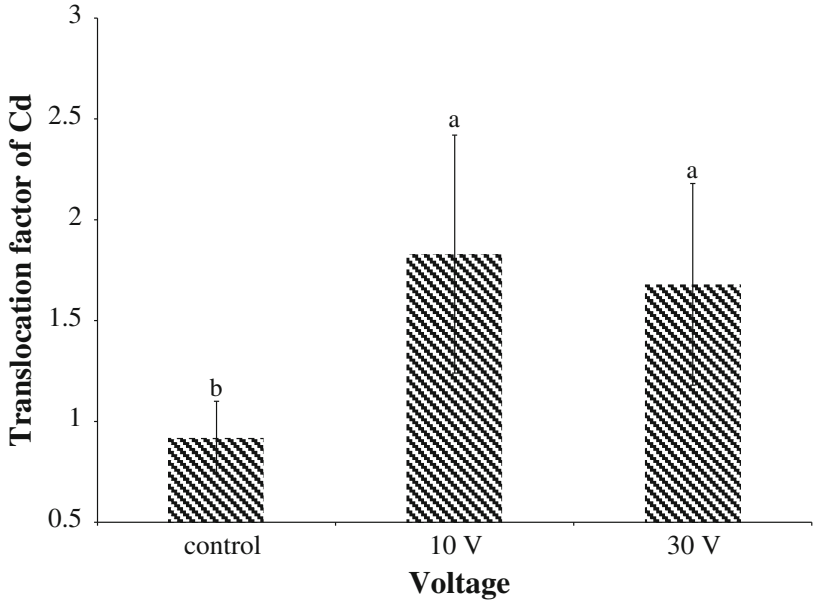

Fig. 2 Cadmium translocation factor (TF) in the electrical field treatments. Values with different letters show significant difference at the 0.05 probability level. Thin bars show standard deviation

related to higher plant growth and root dry weight in manure treatments and dilution of absorbed $\mathrm{Cd}$ in root tissue of plant (Safari Sinegani and Ahmadi 2012).

\section{Translocation factor (TF)}

Translocation of the $\mathrm{Cd}$ from the root to the shoot of sunflower is the second step of phytoextraction after the $\mathrm{Cd}$ absorption by root. It has been revealed that the application of chelating agents like EDTA can enhance the translocation of metals from the root to shoot (Barber and Lee 1974; Hamon et al. 1995; Vassil et al. 1998; Gleba et al. 1999; Safari Sinegani and Khalilikhah 2011). Result of this experiment showed that the translocation of $\mathrm{Cd}$ from the root to shoot was not affected by chelating agents maybe because of the late time of application of the chelating agents or equal changing in concentration of $\mathrm{Cd}$ in shoots and roots; however, it was affected by application of the electrical fields (Table 1). Studying the TF of Cd showed an appreciable increase by application of the electrical treatment (Fig. 2). The values of TF increased more than 98 and $82 \%$ in 10 and $30 \mathrm{~V}$ treated plant compared with 


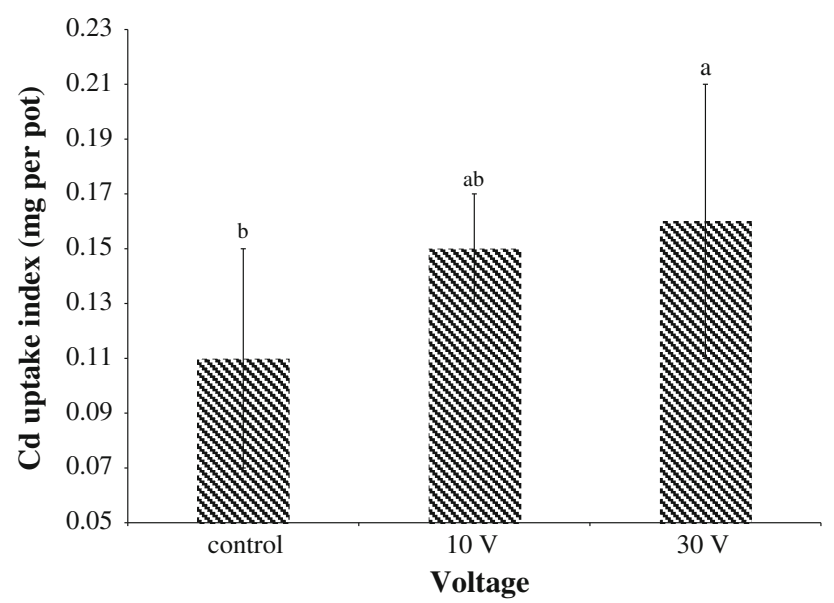

Fig. 3 Cadmium uptake index (UI) by Helianthus annuus $\left(\mathrm{mg} \mathrm{pot}^{-1}\right.$ ) in the electrical field treatment. Values with different letters show significant differences at the 0.05 probability level. Thin bars show standard deviation

the control, respectively. Maximum TF was calculated in $10 \mathrm{~V}$ (1.83), and minimum TF was obtained in control (0.92); however, no significant difference was observed between 10 and $30 \mathrm{~V}(1.68)$.

\section{Metal uptake index (UI)}

Production of plant biomass as well as the concentration of the $\mathrm{Cd}$ in shoot is an important factor affecting the efficiency of $\mathrm{Cd}$ phytoremediation of soil. In this experiment, treating the soil with the chelating agents seems to have not had significant impacts on Cd UI (Table 1). This finding is in contrast to the other reports. EDTA is found to be the most effective chelating agent to enhance heavy metal bioaccumulation (Ebbs et al. 1997; Huang et al. 1997; Wu et al. 1999; Safari Sinegani and Khalilikhah 2011). This difference may be related to the time of application of the chelating agents. Here, we use chelating agents very late for lowering its possible toxicity to plant. Nevertheless, application of the electrical field and plant charging had a significant effect on $\mathrm{Cd}$ uptake by plant (Table 1). It resulted in higher Cd uptake by $H$. annuus (Fig. 3). The amount of UI increased from 0.11 in control to 0.16 in $30 \mathrm{~V}$ treated plants. There was no significant difference between the $10 \mathrm{~V}$ and control and also 10 and $30 \mathrm{~V}$ while control was significantly lower than $30 \mathrm{~V}$. It was reported that a certain electrical field is proven to make biomembranes more permeable without damaging membrane structures (Neumann and Rosenheck 1972, 1973; Kinosita and Tsong 1997). The induced permeability leading to a transient exchange of matter across the perturbed membrane structure (Rosenheck et al. 1975; Lindner et al. 1977) may in turn result in more Cd uptake by plant. Also, role of the electrical gradient from soil toward the plant shoot should not be ignored in this study. Negatively charged plant can absorb and translocate $\mathrm{Cd}$ from soil to upper parts effectively.

Obtained correlation coefficients between Cd UI and the shoot dry weight, Cd concentration in shoot and Cd TF were positive and significant (Table 4). Here, the negative correlation between $\mathrm{TF}$ and root $\mathrm{Cd}$ concentration was predictable because the value of $\mathrm{TF}$ is increased by increasing $\mathrm{Cd}$ concentration in shoot and decreasing $\mathrm{Cd}$ concentration in root. These findings may be related to the applied electrical fields as discussed earlier.

\section{Soil available $\mathrm{Cd}$}

One of the common methods used to determine plant bioavailable heavy metals in soil is DTPA test "a nonequilibrium extraction" developed by Lindsay and Novell in 1987 (Kirkham 2006). In this experiment, a significant $(p<0.01)$ interaction was observed between the electricity and chelating agent treatments on the available (DTPA extracted) Cd in soil (Table 1). Table 5 shows the means of soil available $\mathrm{Cd}$ in different treatments of chelating agents and electrical fields in soils near the root system (NRS) and FFRS.

Test of the soil available $\mathrm{Cd}$ at the end of the experiment illuminated that the highest amount of available Cd in NRS soil was measured in no voltage-PME $\left(0.14 \mathrm{mg} \mathrm{kg}^{-1}\right)$ without any significant difference with $30 \mathrm{~V}$-control $\left(0.12 \mathrm{mg} \mathrm{kg}^{-1}\right)$. But the soil NRS in $30 \mathrm{~V}$-EDTA treatment had the lowest available $\mathrm{Cd}\left(0.003 \mathrm{mg} \mathrm{kg}^{-1}\right)$. The changes of available $\mathrm{Cd}$ in the FFRS soil were almost similar to that in the NRS soil. The maximum $\left(0.13 \mathrm{mg} \mathrm{kg}^{-1}\right)$ and the minimum $\left(0.005 \mathrm{mg} \mathrm{kg}^{-1}\right)$ concentration of available $\mathrm{Cd}$ in FFRS soil were detected in the $30 \mathrm{~V}$-control and $30 \mathrm{~V}$-EDTA treatments, respectively. High amount of $\mathrm{Cd}$ uptake by plant may be responsible for the low available $\mathrm{Cd}$ concentration in the $30 \mathrm{~V}$-EDTA treatment although there is no significant correlation between the DTPA extractable $\mathrm{Cd}$ and concentration of $\mathrm{Cd}$ in plant organs (Table 4).

In general, cathodic soil that was NRS in 10 and $30 \mathrm{~V}$ treatments compared with anodic soil (FFRS) had relatively lower available $\mathrm{Cd}$, which maybe because of better $\mathrm{Cd}$ absorption and acquisition in negatively charged plants or increasing in insoluble form of $\mathrm{Cd}$. This difference was reverse in soils treated with chelating agents with no application of electrical fields (Table 4). In the no voltage treatment, Cd availability was markedly higher in soil NRS especially in PME and CME treatments, which maybe because of higher soil biological activity. Safari Sinegani and Ahmadi (2012) found that soil $\mathrm{Pb}$ and $\mathrm{Cd}$ in soluble and exchangeable fractions were increased by manure applications in cannabis cultivation. 
Table 4 Linear correlation coefficients between analyzed factors in soil near the root system of sunflower

\begin{tabular}{|c|c|c|c|c|c|c|c|c|}
\hline & $\mathrm{pH}$ & SDW & RDW & Sh conc. & R conc. & $\mathrm{TF}$ & $\mathrm{UI}$ & A. $\mathrm{Cd}$ \\
\hline $\mathrm{pH}$ & 1 & & & & & & & \\
\hline SDW & 0.04 & 1 & & & & & & \\
\hline RDW & 0.03 & $0.42 *$ & 1 & & & & & \\
\hline Sh conc. & -0.17 & -0.25 & -0.3 & 1 & & & & \\
\hline $\mathrm{R}$ conc. & -0.26 & $-0.35^{*}$ & -0.24 & 0.32 & 1 & & & \\
\hline TF & 0.13 & 0.15 & 0.08 & $0.46 * *$ & $-0.46 * *$ & 1 & & \\
\hline UI & -0.11 & $0.52 * *$ & 0.05 & $0.64 * *$ & -0.02 & $0.53 * *$ & 1 & \\
\hline A. $\mathrm{Cd}$ & 0.16 & -0.13 & -0.17 & -0.12 & $<0.01$ & -0.16 & -0.20 & 1 \\
\hline
\end{tabular}

$S D W$ shoot dry weight, $R D W$ root dry weight, Sh conc. shoot Cd concentration, $R$ conc. root Cd concentration, $T F \mathrm{Cd}$ translocation factor, $U I \mathrm{Cd}$ uptake index, $A$. $C d$ available (DTPA extractable) $\mathrm{Cd}$

* Correlation is significant at the 0.05 ; ** correlation is significant at the 0.01

Table 5 Available (DTPA extractable) $\mathrm{Cd}\left(\mathrm{mg} \mathrm{kg}^{-1}\right)$ in NRS and FFRS of Helianthus annuus in application of different electrical fields and chelating agents

\begin{tabular}{lccc}
\hline & $30 \mathrm{~V}$ & $10 \mathrm{~V}$ & No voltage \\
\hline NRS & & & \\
CME & $0.04^{\mathrm{d}}( \pm 0.007)$ & $0.009^{\mathrm{e}}( \pm 0.007)$ & $0.10^{\mathrm{c}}( \pm 0.01)$ \\
PME & $0.04^{\mathrm{d}}( \pm 0.002)$ & $0.05^{\mathrm{d}}( \pm 0.01)$ & $0.14^{\mathrm{a}}( \pm 0.01)$ \\
EDTA & $0.003^{\mathrm{e}}( \pm 0.003)$ & $0.11^{\mathrm{bc}}( \pm 0.01)$ & $0.04^{\mathrm{d}}( \pm 0.02)$ \\
Control & $0.12^{\mathrm{ab}}( \pm 0.01)$ & $0.04^{\mathrm{d}}( \pm 0.01)$ & $0.005^{\mathrm{e}}( \pm 0.009)$ \\
FFRS & & & \\
CME & $0.04^{\mathrm{cd}}( \pm 0.01)$ & $0.10^{\mathrm{ab}}( \pm 0.006)$ & $0.08^{\mathrm{bc}}( \pm 0.02)$ \\
PME & $0.06^{\mathrm{cd}}( \pm 0.01)$ & $0.03^{\mathrm{de}}( \pm 0.01)$ & $0.09^{\mathrm{b}}( \pm 0.02)$ \\
EDTA & $0.005^{\mathrm{e}}( \pm 0.005)$ & $0.11^{\mathrm{ab}}( \pm 0.02)$ & $0.07^{\mathrm{bc}}( \pm 0.03)$ \\
Control & $0.13^{\mathrm{a}}( \pm 0.01)$ & $0.06^{\mathrm{cd}}( \pm 0.02)$ & $0.03^{\mathrm{de}}( \pm 0.03)$ \\
\hline
\end{tabular}

Values with different letters show significant differences at the 0.05 probability level for each soil

$N R S$ soil near the root system, FFRS soil far from root system, $C M E$ cow manure extract, $P M E$ poultry manure extract

\section{Conclusion}

In this experiment, the effects of EDTA, CME, and PME as chelating agents and using the plant as a cathode on the phytoremediation indices were investigated. Application of chelating agents and electrical fields had no significant impacts on shoots and roots dry weights of $H$. annuus, except that EDTA reduced roots dry weight. Treating the plants with EDTA along with increasing the voltage of electrical fields increased the concentration of Cd in plants' shoots. None of the chelating agents had significant impacts on $\mathrm{Cd}$ uptake and acquisition by $H$. annuus. Highest $\mathrm{Cd} \mathrm{TF}$ was measured in $10 \mathrm{~V}$ treatment, while Cd UI increased by increasing the voltages so that the highest UI was obtained in the $30 \mathrm{~V}$ with no significant difference with $10 \mathrm{~V}$. Based on the obtained results of the current experiment, charging the plant with DC electricity, which could be recognized and improved as a new method of phytoextraction, enhanced the efficiency of $\mathrm{Cd}$ phytoremediation.

Acknowledgments The authors were grateful to Amir Mehdi Mahshanian for editing the article and to the reviewers for their valuable comments.

\section{References}

Alcantara MT, Gómez J, Pazos M, Sanromán MA (2012) Electrokinetic remediation of lead and phenanthrene polluted soils. Geoderma 173-174:128-133

Baek K, Kim DH, Park SW, Ryu BG, Batjargal T, Yang JS (2009) Electrolyte conditioning-enhanced electrokinetic remediation of arsenic-contaminated mine tailing. J Hazard Mater 161:457-462

Barber SA, Lee RB (1974) The effect of micro-organisms on the absorption of manganese by plants. New Phytol 73:97-106

Bi R, Schlaak M, Siefert E, Lord R, Connolly H (2011) Influence of electrical fields (AC and DC) on phytoremediation of metal polluted soils with rapeseed (Brassica napus) and tobacco (Nicotiana tabacum). Chemosphere 83:318-326

Bower CA, Reitemeier RF, Fireman M (1952) Exchangeable cation analysis of saline and alkali soils. Soil Sci 73:251-261

Cang L, Wang QY, Zhou DM, Xu H (2011) Effects of electrokineticassisted phytoremediation of a multiple-metal contaminated soil on soil metal bioavailability and uptake by Indian mustard. Sep Purif Technol 79:246-253

Chen JL, Yang SF, Wu CC, Ton S (2011) Effect of ammonia as a complexing agent on electrokinetic remediation of coppercontaminated soil. Sep Purif Technol 79:157-163

Cooper M, Sims JT, Cunningham SD, Huang JW, Berti WR (1999) Chelate-assisted phytoextraction of lead from contaminated soils. J Environ Qual 28:1709-1719

Dede G, Ozdemir S, Hulusi Dede O (2012) Effect of soil amendments on phytoextraction potential of Brassica juncea growing on sewage sludge. Int J Environ Sci Technol 9(3):559-564

Ebbs SD, Lasat MM, Brady DJ, Cornish J, Gordon R, Kochian LV (1997) Phytoextraction of cadmium and zinc from a contaminated soil. J Environ Qual 26:1424-1430

Elliott HA, Brown GA (1989) Comparative evaluation of NTA and EDTA for extractive decontamination of $\mathrm{Pb}$-polluted soils. Water Air Soil Pollut 45:361-369

Figueroa JAL, Wrobel K, Afton S, Caruso JA, Corona JFG, Wrobel K (2008) Effect of some heavy metals and soil humic substances 
on the phytochelatin production in wild plants from silver mine areas of Guanajuato, Mexico. Chemosphere 70:2084-2091

Fleischer M, Sarofim AF, Fassett DW, Hammond P, Shacklette HT, Nisbet ICT, Epstein S (1974) Environmental impact of cadmium: a review by the panel on hazardous trace substances. Environ Health Perspect 7:253-323

Giannis A, Gidarakos E, Skouta A (2007) Application of sodium dodecyl sulfate and humic acid as surfactants on electrokinetic remediation of cadmium-contaminated soil. Desalination 211:249-260

Giannis A, Pentari D, Wang JY, Gidarakos E (2010) Application of sequential extraction analysis to electrokinetic remediation of cadmium, nickel and zinc from contaminated soils. J Hazard Mater 184:547-554

Gleba D, Borisjuk NV, Borisjuk LG, Kneer R, Poulev A, Skarzhinskaya M, Duskenkov S, Logendra S, Gleba YY, Raskin I (1999) Use of plant root for phytoremediation and molecular farming. Proc Natl Acad Sci 96:5973-5977

Gomes HI, Dias-Ferreira C, Ribeiro AB (2012) Electrokinetic remediation of organochlorines in soil: enhancement techniques and integration with other remediation technologies. Chemosphere 87:1077-1090

Haag-Kerwer A, Schäfer HJ, Heiss S, Walter C, Rausch T (1999) Cadmium exposure in Brassica juncea causes a decline in transpiration rate and leaf expansion without effect on photosynthesis. J Exp Bot 50:1827-1835

Hamon RE, Lorenz SE, Holm PE, Christensen TH, McGrath SP (1995) Changes in trace metal species and other components of the rhizosphere during growth of radish. Plant Cell Environ 18:749-756

Hernandez-Allicac J, Garbisu C, Barrutia O, Becerril JM (2007) EDTA-induced heavy metal accumulation and phytotoxicity in cardoon plants. Environ Exp Bot 60:26-32

Huang JW, Chen J, Berti WR, Cunningham SD (1997) Phytoremediation of lead-contaminated soils: role of synthetic chelates in lead phytoextraction. Environ Sci Technol 31:800-805

Kabata-pendias A (2011) Trace elements in soils and plant. CRC Press: an imprint of the Taylor \& Francis Group, Boca Raton

Kim SO, Kim KW, Stuben D (2002) Evaluation of electrokinetic removal of heavy metals from tailing soils. J Environ Eng ASCE 128:705-715

Kim DH, Jeon CS, Baek K, Ko SW, Yang JS (2009) Electrokinetic remediation of fluorine-contaminated soil: conditioning of anolyte. J Hazard Mater 161:565-569

Kinosita KJR, Tsong TY (1997) Voltage-induced pore formation and hemolysis of human erythrocytes. Biochim Biophys Acta 471:227-242

Kirkham MB (2006) Cadmium in plants on polluted soils: effects of soil factors hyperaccumulation, and amendments. Geoderma 137:19-32

Klute A (ed) (1986) Methods of soil analysis: Part I. Physical and mineralogical methods, 2nd edn. Soil Sci Soc Am Agron Monogr 9, WI, USA

Kulli B, Balmer M, Krebs R, Lothenbach B, Geiger G, Schulin R (1999) The influence of nitrilotriacetate on heavy metal uptake of lettuce and ryegrass. J Environ Qual 28:1699-1705

Li F, Qu X, Wu L, et al. (2006) Bioremediation of contaminated soil: fundamental theory and technology. Chemical Industry Press, Book in Chinese

Li T, Yuan S, Wan J, Lin L, Long H, Wu X, Lu X (2009) Pilot-scale electrokinetic movement on $\mathrm{HCB}$ and $\mathrm{Zn}$ in real contaminated sediments enhanced with hydroxypropyl-ß-cyclodextrin. Chemosphere 76:1226-1232

Lim JM, Salido AL, Butcher DJ (2004) Phytoremediation of lead using Indian mustard (Brassica juncea): with EDTA and electrodics. Microchem J 76:3-9

Lindner P, Neumann E, Rosenheck K (1977) Kinetics of permeability changes induced by electric impulses in chromaffin granules. J Membr Biol 32:231-254
Lindsay WL, Norvell WA (1978) Development of a DTPA soil test for zinc, iron, manganese and copper. Soil Sci Soc Am J 42:421-428

Neumann E, Rosenheck K (1972) Permeability changes induced by electric impulses in vesicular membranes. J Membr Biol 10:279-290

Neumann E, Rosenheck K (1973) Potential difference across vesicular membranes. J Membr Biol 14:194-196

O'Connor CS, Lepp NW, Edwards R, Sunderland G (2003) The combined use of electrokinetic remediation and phytoremediation to decontaminate metal-polluted soils: a laboratory-scale feasibility study. Environ Monit Assess 84:141-158

Page AL, Miller RH, Keeney DR (eds) (1992) Methods of soil analysis. Part 2. Chemical and microbiological methods, 2nd edn. Soil Sci Soc Am Agron Monogr 9, WI, USA

Pazos M, Rosales E, Alcántara T, Gómez J, Sanromán MA (2010) Decontamination of soils containing PAHs by electroremediation: a review. J Hazard Mater 177:1-11

Rosenheck K, Lindner P, Pecht I (1975) Effect of electric fields on light-scattering and fluorescence of chromaffin granules. J Membr Biol 20(1-2):1-12

Safari Sinegani AA, Ahmadi P (2012) Manure application and cannabis cultivation influence on speciation of lead and cadmium by selective sequential extraction. Soil Sediment Contam 21:305-321

Safari Sinegani AA, Khalilikhah F (2011) The effect of application time of mobilising agents on growth and phytoextraction of lead by Brassica napus from a calcareous mine soil. Environ Chem Lett 9:259-265

Salt DE, Smith RD, Raskin I (1998) Phytoremediation. Annu Rev Plant Phys Plant Mol Biol 49:643-668

Shi WY, Shao HB, Li H, Shao MA, Du S (2009) Progress in the remediation of hazardous heavy metal-polluted soils by natural zeolite. J Hazard Mater 170:1-6

Smolders E, Degryse F (2006) Fixation of cadmium and zinc in soils: implication for risk assessment. In: Hamon R, McLaughlin M, Lombi E (eds) Natural attenuation of trace element availability in soils. Taylor \& Francis, Boca Raton, pp 157-171

Sposito G, Lund J, Change AC (1982) Trace metal chemistry in arid zone field soils amended with sewage sludge: I. Fractionation of $\mathrm{Ni}, \mathrm{Cu}$, and $\mathrm{Pb}$ in solid phase. Soil Sci Soc Am J 46:260-264

Street JJ, Lindsay WL, Sabey BR (1977) Solubility and plant uptake of cadmium in soils amended with cadmium and sewage sludge. J Environ Qual 6:72-77

United States Environmental Protection Agency (USEPA) (2000) Introduction to phytoremediation (EPA 600/R-99/107). United States Environmental Protection Agency, Office of Research and Development, Cincinnati

Vassil AD, Kapulnik Y, Raskin I, Salt DE (1998) The role of EDTA in lead transport and accumulation in Indian mustard. Plant Physiol 117:447-453

Wang QY, Zhou DM, Cang L, Sun TR (2009) Application of bioassays to evaluate a copper contaminated soil before and after a pilot-scale electrokinetic remediation. Environ Pollut 157:410-416

Williams CH, David DJ (1976) The accumulation in soil of cadmium residues from phosphate fertilizers and their effect on the cadmium content of plants. Soil Sci 121(2):86-93

Williams CH, David DJ (1981) The effect of superphosphate on the cadmium content of soils and plants. Aust J Soil Res 11:43-56

Wong JWC, Wong WWY, Wei Z, Jagadeesan H (2004) Alkaline biosolids and EDTA for phytoremediation of an acidic loamy soil spiked with cadmium. Sci Total Environ 324:235-246

Wu J, Hsu FC, Cunningham SD (1999) Chelate-assisted Pb phytoextraction: $\mathrm{Pb}$ availability, uptake, and translocation constraints. Environ Sci Technol 33:1898-1904

Zhou DM, Cang L, Alshawabkeh AN, Wang YJ, Hao XZ (2006) Pilot-scale electrokinetic treatment of a $\mathrm{Cu}$ contaminated red soil. Chemosphere 63:964-971 